\title{
USE OF OFFICIAL STATISTICAL DATA AND METHODOLOGY IN TEACHING THE SUBJECT «ESSENTIAL NATIONAL ACCOUNTING»
}

\author{
Ruslan Motoryn \\ Lublin University of Technology, Poland \\ Tetiana Motoryna, Kateryna Prykhodko \\ Taras Shevchenko National University of Kyiv, Ukraine \\ motoryn@i.ua
}

\section{INTRODUCTION}

Content of teaching Essential National Accounting has transition to the International Standards. Statistics have wide spreading all over the globe. Today practically all countries and international organisations rely on the System of National Accounts (SNA) for evaluating economic performance, setting goals, etc. It is necessary to use the specialities of Internet for it learning by universities experience of the world best practice. We elaborated course "Essential National Accounting" for the training of official statisticians and teaching of students of Universities of Economics. We have used the data of Ukrainian Statistical Office, Central Bank of Ukraine and Global Statistics by Internet for the formation of Curricula for specialists on Statistics of the Taras Shevchenko National University of Kyiv and others Universities of Ukraine.

\section{CONTAIN OF THE ESSENTIAL NATIONAL ACCOUNTING COURSE}

The topics covered by this course, as a rule, include: the source of the SNA, the history of the UN SNA, general description of the UN SNA-2008, the Current Accounts block, the Accumulation Accounts block, the Balance Sheets block, Goods and Services Account, the Rest of the World Account aggregates in the SNA, the peculiarities of the SNA structure in Ukraine, implementation of the SNA date for macroeconomic analysis and modelling and some other topics.

The discussion above aimed to prepare the field to a more practical part of the course: the one, which deals with the problems of measuring economic activity and the building of the macroeconomic aggregates. The first point to be made is that the definitions of macroeconomic aggregates follow from the manner in which the economic system is being defined and the function attributed to that system within the larger set of social institutions.

Put in this way, students attention should be drawn to the fact that what is to be measured depends on the question being addressed. For example, GDP is a good measure of the level of market activities, but if the objective of a study is to measure economic welfare, the performance of the overall economic system, both the market and non- market sectors, should be accurately considered.

The presentation of the discussion about the building of the main macroeconomic aggregates and their meaning should be followed by the presentation of the structure of the new system of National Accounts.

\section{CONCLUSION}

In conclusion, teaching essential national accounting is not so easy. The knowledge about the survey and preparation of empirical data, the competent use of already given data sources, as for example data from the official statistics, as well as the use of data and experiences of scientists from other countries have shown great deficits within and out of universities in Ukraine. Specialists of economics, management, statistics, international economy and other needs knowledge about the SNA. 